\title{
NEWS BRIEFING
}

\section{POLICY}

Oil spill: The oil spewing into the Gulf of Mexico was partially stemmed this week, after BP managed to force a siphon tube into the leaking wellhead pipe. But the political fallout intensified as Congress sought answers about the explosion of the Deepwater Horizon rig. US interior secretary Ken Salazar said on 11 May that the Minerals Management Service would be split up, separating safety and environmental operations from its oil-leasing arm. For more on the spill, see pages 274-275.

Lab fix needed: NASA's ageing research labs are in dire need of an overhaul, according to a report released on 11 May by the National Academies. Some 80\% of the agency's research facilities are more than 40 years old, and its deferred-maintenance bill has risen from US $\$ 1.77$ billion in 2004 to $\$ 2.46$ billion in 2009. US President Barack Obama's proposed 2011 budget for the agency would rectify some problems by transferring money from the cancelled Constellation moon-rocket programme to longterm technology-development and research. But legislators in Congress have so far fought the President's budget plan.

US spending hitch: The House of Representatives unexpectedly shot down science and education legislation on 13 May after Republicans raised concerns about the federal budget deficit and about government employees, including some at the National Science Foundation, viewing Internet pornography sites. The legislation would have authorized future spending under the 2007 America COMPETES Act, which called for a doubling of research funding in the physical sciences. See go.nature. com/aSMYlX for more.

Medical disarray: The Indian government on 15 May took over the Medical Council of India (MCI), three weeks after

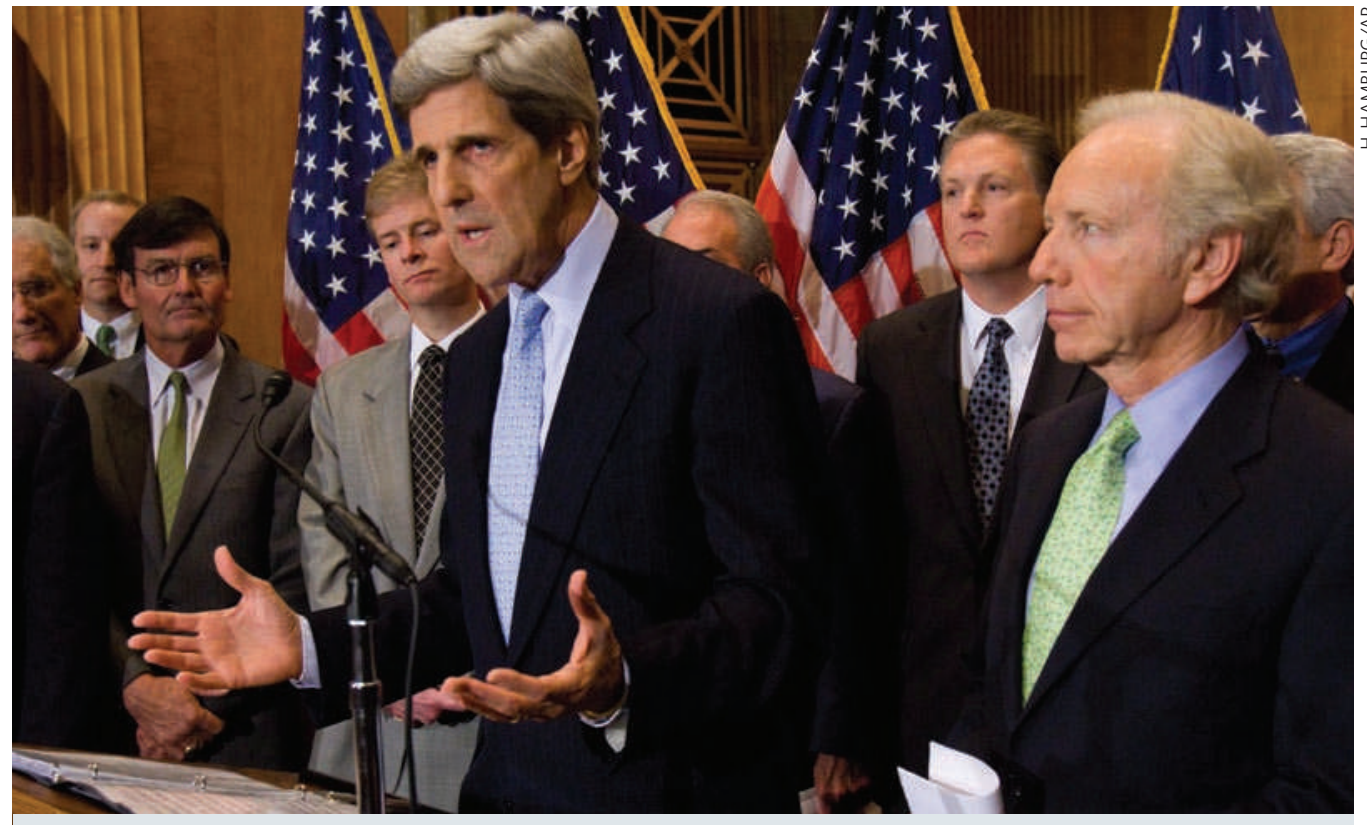

\section{NEW CLIMATE BILL ARRIVES IN US SENATE}

US senators John Kerry (Democrat, Massachusetts; pictured centre) and Joseph Lieberman (Independent, Connecticut; pictured right) released their much-anticipated climate legislation on 12 May, setting the stage for one last attempt at getting climate legislation through the current Congress before the midterm elections in November. The bill would use a cap-and-trade scheme to curb emissions by $17 \%$ by 2020 , and by some $80 \%$ by 2050 (relative to 2005 levels). It contains mechanisms intended to stabilize carbon prices and make costs predictable for industry (see go.nature.com/2mpfSN). A day later, the Environmental Protection Agency turned up the pressure on Congress by releasing a rule clarifying how greenhouse-gas emission restrictions would be phased in for major industrial polluters beginning next year - if Congress fails to enact climate legislation.

its president, Ketan Desai, was arrested on corruption charges (see Nature 464, 1251; 2010). An ordinance signed by Indian President Pratibha Devisingh Patil establishes a board of governors to run the council for one year. During that year, the government may also dissolve the MCI, which sets and maintains standards of medical education and accredits Indian medical schools.

\section{RESEARCH}

Stimulus salvo: On 14 May, the US National Institutes of Health doled out the final big chunk of new awards to be funded from its US\$10.4-billion 2009 economic stimulus package: $\$ 1$ billion to construct, repair and renovate research labs at extramural institutions in 44 states, Puerto Rico and the District of Columbia. The 146 individual

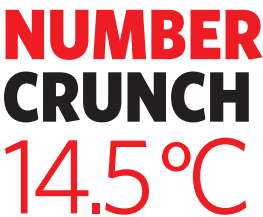

April's combined land and sea surface temperature: the hottest April on record, at $0.76^{\circ} \mathrm{C}$ above the average for the twentieth century. grants include \$7.4 million to the University of Alaska in Fairbanks for building clinicaltrial facilities to study health disparities in Native Americans, and $\$ 15$ million to the University of Colorado at Boulder for a new biotechnology facility housing 60 faculty members and more than 500 graduate students, researchers and support staff.

Laboratory fire: A fire at a research centre in São Paulo, Brazil, has destroyed a leading collection of dead snakes. The state-funded Butantan Institute, which was nearly 100 years old, contained around 80,000 preserved snakes and thousands of spiders and scorpions that were used for biomedical research. The curator Franciso Franco has told press agencies that its destruction on 15 May was a "loss to humanity". The cause of the fire is being investigated. 
Phones and cancer: There is no clear link between mobilephone use and the risk of brain cancer, according to a major study published this week (The INTERPHONE Study Group Int. J. Epidemiol. doi:10.1093/ije/ dyq079; 2010). The study, run by the World Health Organization's International Agency for Research on Cancer in Lyon, France, interviewed thousands of adults with and without cancer in 13 countries about their mobilephone usage. See go.nature.com/ uZph7a for more.

\section{India defence research: India’s} largest military technology research body is set for a management revamp under government measures announced on 13 May. The 52-year-old state-owned Defence Research \& Development Organisation currently employs more than 5,000 scientists in 51 laboratories. It will be split into seven separately directed centres, such as life sciences and materials science, and projects will be monitored by a new oversight committee. A 2007 review had recommended restructuring the organization after criticisms that projects such as combat aircraft and guided missiles encountered huge time and cost overruns.

\section{BUSINESS}

\section{Genome shopping: The US} pharmacy chain Walgreens postponed plans to start selling a personal genome-testing kit in thousands of its shops last week, after the Food and Drug Administration began an investigation into whether the

\section{NEWS MAKER}

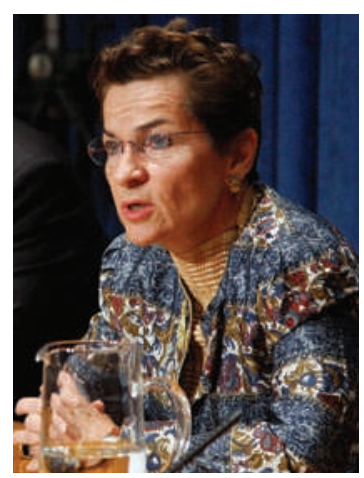

Christiana

\section{Figueres}

The Costa Rican diplomat, 53, is the new head of the United Nations Framework Convention on Climate Change, succeeding Yvo de Boer.

kits require regulatory approval. The $\$ 30$ saliva-collection kit is manufactured by Pathway Genomics, a direct-to-consumer genetic-testing company based in San Diego, California. Shoppers would have to send their DNA sample to the company's laboratory for a customized genetic report costing \$79-249. The kit is already available to order online.

Chinese solar: Jinko Solar, one of several Chinese firms hoping to dominate the crowded silicon photovoltaic market, received a cautious welcome at its 14 May initial public offering on the New York Stock Exchange. The company, based in Shanghai, raised some US $\$ 64$ million at $\$ 11$ per share - a price at the lower end of its predicted range, and which stayed at that level throughout the day. It will use the money to expand manufacturing capacity.

Cancer acquisition: Astellas Pharma, headquartered in Tokyo, Japan, said on 16 May that it had agreed to pay US $\$ 4$ billion to purchase OSI Pharmaceuticals, based in New York. The US firm is best known for its anticancer drug erlotinib (Tarceva).

\section{PEOPLE}

UK science minister: David

Willetts has been named as Britain's minister for universities and science. He was appointed on 12 May, after a coalition government had been formed between the Conservative and Liberal Democrat parties. Willetts, 54, studied philosophy, politics and economics at the University of Oxford, and has been a Member of Parliament since 1992. He was the Conservative Party's shadow minister for innovation, universities and skills for the three years leading up to the 6 May general election.

\section{THE WEEK AHEAD}

\section{0-22 MAY}

Mouse models of autism are one of the items on the agenda at the international meeting for autism research, which convenes in Philadelphia, Pennsylvania. www.autism-insar.org

\section{MAY}

This year's International Day for Biological Diversity (as proclaimed by the United Nations) has been allotted the theme of poverty and development.

www.cbd.int/idb

\section{3-27 MAY}

The American Astronomical Society holds its 216th meeting in Miami, Florida.

aas.org/meetings/aas216

\section{Varmus return: Nobel laureate} Harold Varmus is to be the next director of the US National Cancer Institute at the National Institutes of Health (NIH), replacing John Niederhuber. The \$5.1-billion cancer institute is the largest of the NIH's 27 institutes and centres. Varmus, whose appointment was announced on 18 May, headed the NIH during the Clinton administration, between 1993 and 1999, and then became president of the Memorial Sloan-Kettering Cancer Center in New York, before advising Barack Obama during his run for the presidency.

\section{BUSINESS WATCH}

Investors are losing confidence in Monsanto, the agricultural biotech giant based in St Louis, Missouri (see chart). Some farmers aren't seeing big yield increases with the company's new herbicide-tolerant soya bean line, Roundup Ready 2 Yield. They are also hesitant about buying its forthcoming SmartStax maize (corn), which incorporates eight genes conferring herbicide tolerance and insect protection. If farmers don't switch to Roundup Ready 2, the company's profits may suffer, as the original Roundup Ready trait goes off patent in 2014.

According to Laurence Alexander, an analyst at investment bank Jefferies, headquartered in New York City, Monsanto is being squeezed in the North American soya and maize market by the world's number-two seed company DuPont, which owns plant-genetics firm Pioneer Hi-Bred International, based in Johnston, lowa. Alexander worries that Monsanto will cut prices to protect its share, which could potentially hurt its research budget. But on 5 May, Carl Casale, Monsanto's executive vice-president and chief financial officer, said research spending was not in jeopardy. Meanwhile, Swiss firm Syngenta, based in Basel, is flexing its muscles with the imminent release of its herbicide-tolerant, insect-resistant Viptera maize. In the longer term, the three firms will also be vying to offer farmers drought-tolerant maize.

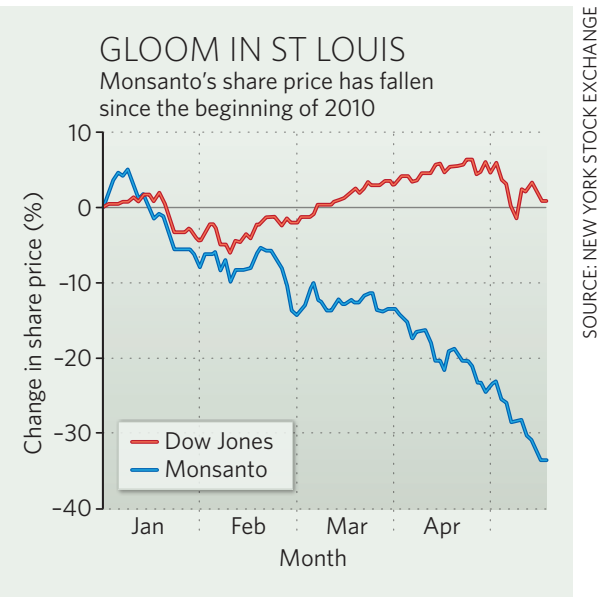

